\title{
Organization and Symbolization of the Folk Belief Opera
}

\author{
Using Nuo Opera Gathering Of Chizhou, Anhui as an Example
}

\author{
Yibin Wang \\ Art College\& Post Doctorate of Management \\ Xiamen University \\ Xiamen, P.R. China \\ e-mail: wyb119@126.com
}

\begin{abstract}
Nuo Opera, being active in South Anhui Province, is considered as the living fossil of Chinese Opera. The simple performance style, ancient singing style, efficacious holiness always unfolds the scenario of "joyful god and happy humans" in local Chizhou city. Nuo Opera Gathering is the form of organization of Chizhou Nuo Opera. Its substance (economy) supplies represent "republicanism" (self-help) and it is the spirit bond connecting collective villagers.
\end{abstract}

Keywords-Nuo Opera of Chizhou; Republicanism;Nuo Opera Gathering Association; Conflict and Compromise

The survival of Chizhou Nuo Opera entirely depends on the conscious act of villagers. In Chizhou City, there is no involvement of any government action, including the deployment of personnel, financial aid or direction in art. Only relying on the memories of the traditions, divine piety and belief in blessing, villagers consciously organize Nuo Opera Gathering and execute the responsibilities of gathering personnel, raising funds and gathering audience. After the disbandment of Nuo Opera Gathering, all members, including the organizer himself, are back to their role as common farmers. In their daily lives, they do not enjoy any privileges. Of course, even though in Nuo Opera Gathering, there are no physical or economic returns, compensation and any other privileges beyond the management scope of Nuo Opera Gathering.

\section{NuO Opera GATHERING}

The daily management organization of Nuo Opera in Chizhou is Nuo Opera Gathering. Each gathering is composed of organizer, deacons, actors, actresses and other people dealing with chores. The organizer is the top decision-maker and chief executive officer. This position is usually taken by prestigious males in the village and it can be taken full-time or by the rotation of several males (the organizer of Nuo Opera Gathering in this year is called "the organizer of the year". In 1980s, when Nuo Opera was allowed to be resumed, the organizer of each Nuo Opera Gathering played very important roles in raising funds, contacting actors, copying and spreading transcripts, making masks and designing costumes. In formal performance time of each year, the organizers only played the role as supervisors. As long as the gatherings are not messed up, they will free their hands and give full authorities to young people for specific implementations.

During the performance of Nuo Opera that is often taken in the first month of Chinese calendar, the organizer is regarded by villagers as the most prestigious arbiter. Whatever happen, big or small, are judged by the organizer whose comment are valued mostly. In some villages, because of the prestige of the organizer, his son could take the highest executive position in the village as village chief or village heads. The prestige the organizers hold definitely will be extended to daily lives. After two or three years, the organizer would become real leader with full support of villagers. In some villages, there are councils composed of several old people to (the photo above is taken by the author. They are the members of the council of Xintianxie group of Puzhuang Village. The second from the left is the organizer Xie Shaopu, the forth from the left is the dead Nuo Opera Expert Wang Zhaoqian) make decisions for group activities in the village.

There are various types of deacons and they can be divided into chief deacon, secondary deacon and ordinary deacon based on the level of ranking; based on their functions, they can be divided into ceremonial deacon, Nuo Opera deacon, Nuo Dance deacon and general deacon. Everyone plays each role and follows the orders of the organizer. Sometimes, when there is a short of personnel, one people could take the responsibilities for two deacons. Deacons are personnel to deal with specific affairs. Each chief deacon leads about 10 ordinary deacons and each deacon is responsible for one specific procedural affair of Nuo Opera.

The actors are the backbone of Nuo Opera and they are divided into singing, performing and dancing actors. Singing actors are further divided into major and minor singing actors. For major singing actors, they are relatively fixed as well as their roles. They are considered as the main inheritors of Nuo Opera. For minor singing actors, they can be replaced at will. As long as someone could sing at the spot, he or she is welcome to join in the team of minor singing actors; For dancing actors, they are relatively fixed 
and different styles of dancing are inherited by different villagers. For all the above groups, except that minor singing actors and ordinary deacons have the involvement of females, the vast majority of Nuo Opera members are males. The relative fixedness of the positions, such as the organizer, chief deacons, chief singing and dancing actors is beneficial to the stable inheritance of Nuo Opera, but when the chief members are not available, Nuo Opera could not be performed in agreed time with normal procedures, which poses some accidental uncertainties to the inheritance of Nuo Opera.

"Republicanism" represents moral values of the organizers and villagers. From the perspective of current agricultural policy and status quo of agricultural economy, Chinese peasants in this stage still live independent natural economy. The noncooperation in the family-based economy definitely brings autonomy of peasant spirits, selfishness in social customs and exclusiveness in cultural characteristics. The traditions over several thousand years still prevail. The traditional selfishness, short-sightedness and preservation are not only the deficits in characters of Chinese peasants in which specific period. Modern Chinese peasants could not shake off the deep rooted bad habits in short time that are accumulated over long period. Sometimes, we are not aware of their existence. However, in our mechanism, in our thoughts, closed small farmer consciousness is silently inherited although some conscious people have been aware of the harms that pose harms on us. Apparently, conscious behavior cannot be effective in short time to overcome unconscious traditions.

"Unconsciousness not only exists in living organic bodies, but also plays significant role in intelligent activities. Psychological consciousness only takes an extremely tiny place in the comparison of unconsciousness. Our conscious behaviors are caused by some certain unconscious genes. This kind of unconscious genes is formed genetic influences in psychology and is composed of common features generations by generations. These features formed the talents of one typical race. There are our admitted reasons behind our behaviors and behind these admitted reasons there are definitely have secret reasons that we are not willing to admit. Most common behavior in our daily lives is caused by some unnoticed hidden motivations."1

Therefore, as a saying goes "if you want to stop risky behavior of sleepwalkers, we have to wake up their brains", if we want to overcome the gifted weakness in unconsciousness, we only wake up our unconscious psychology. Every unconscious state shall correspond to specific states of consciousness and specific daily behaviors accordingly. The best way to waken inside psychological world is to create a realm of "self-denial", a state of self-vanishing, in which only has the sense of collectivism rather than individual.

From the perspective of materialism, Nuo Opera Gathering is only fictional organization; from the level of consciousness, Nuo Opera Gathering is an ideal home to villagers, the happy community helping villagers realize dreams gradually. Regardless of the members of Nuo Opera
Gathering or common villagers, during Nuo Opera Days, only sincerely playing Nuo Opera well and actively being involved in Nuo Opera to entertain villagers is the only thing conducted in the village; Villagers show their own initial hearts to gods for communication; Villagers pray for welfare, longevity and happy rewards. The biggest purpose of Nuo Opera Gathering is to win welfares for the whole villagers. During the whole Nuo Opera activities, the greatest difference for villagers is that they show their sense of collectivism in their characters than daily lives.

All of activities in Nuo Opera Gathering are dominated by collective willpower of whole villagers rather than individual consciousness of the organizer. Nuo Opera Gathering shoulders good wishes of all villagers and realizes the experience and regress of gregarious living conditions. Furthermore, in modern industrial society, it also needs close cooperation among people and Nuo Opera Gathering appropriately helps villagers retrieve hidden sense of cooperation. In facts, "Human beings are gregarious animals and always keep sense of gregariousness in their inner mind. For example, the reasons why people go to cinema are, on one hand, the expression of gregariousness in psychology; on the other hand, the exchange in aesthetic emotions among people. One of the most attractive and mysterious features is that audience always have same reaction and same feelings. In the process of stage performance, regardless of actors, actresses and audience themselves, the same reaction become more and more obvious. Every actor or actress who has the experience of stage performance will believe that the reaction to the same play is definitely true. In some sense, audience is no longer isolated individuals and they share the same collectivism."2

In Nuo Opera of Pu Village, we saw a flag who led Nuo Opera Team, saying "Republicanism" in Chinese. This flag is shouldered by a deacon and the other head of flag pole hangs large attention-getting clamor. We immediately consulted this deacon but he could not offer the reasons. He only knew that since the restoration of Nuo Opera, it became tradition. Later, in memorial temple of Xingtianxie Village, I asked this for Mr. Xie Shaopu, the organizer of Nuo Opera. He answered that "republicanism represents republic country". I again asked this for Mr. Wang Zhaoqian, researcher and expert on Nuo Opera. Mr. Wang replied that since the very beginning of the 20th Century, Nuo Opera had the flag like this. Flag of "Republicanism" is closely related with the dream and expectation striving for "republicanism" with the basic meaning of "everyone does come”!

According to common argument and the origins and areas of application of the flag of "republicanism", we can reach the conclusion for the functions and meanings of "Flag of Republicanism of Nuo Opera in Chizhou". The initial purpose of the flag of "republicanism"is to call and assemble. Holding flag pole on the back of deacons, having large attention-getting clamor in the front and the flag of "republicanism" in the back of Nuo Opera Team follows the agreed tradition of clamor in the front of team in Chinese traditional cultural arts. This tradition has a long history and the purpose of this tradition is to disperse all disease demons 
and laity to make way for the sacred, the souls of their ancestors and heroes. Of course, the villagers hearing the clamor or seeing the flag will gather around the Nuo Opera Team unintentionally to the public place in villages. Therefore, clamor in acoustics and flag in sensory also play the role for calling and assemble. It is not only conducted to invite the holy spirits in the heaven, but also to call ordinary villagers. In this case, it is easy to understand the meaning of the initial purpose of the flag of "republicanism" that is to strengthen the collectivism among villagers.

Nuo Opera Gathering is the expression of collective consciousness and unconsciousness of whole villagers. It shall be conducted through specific various ways. The flag of "republicanism" not only waken Holy Spirit and villagers, but also realizes the channeling of feelings, knowledge and structure of the heaven, the earth and the people in Nuo Opera. These opera rituals require joint involvement, Nuo Dance needs joint performance and Nuo Opera demands joint singing. The audience often becomes "crazy" in witnessing the opera, the state of fancy. Sometimes, actors will have fancy of "devoting themselves into the Opera". In this time and space, Holy Spirit will come down naturally. It creates republicanism between people and people, between opera and opera, between gods and gods. The purpose on the job site is to realize republicanism between people and gods and the purpose in real life is to realize republicanism between people and people. The saying that interprets the meaning of "republicanism" into the republicanism carried in "republican country" is definitely not a false analogy.

Ancient Greek drama originated from Dionysian worship. In the state of "Liquormania", people temporarily forgot their identity of common people and made their lives dramatized, artistic and dramatic. In the very beginning, few people were gathered together in semi-circular hillside area and interpreted stories, which called "show". Later, the "show" is gradually transformed into artistic performance of singing and dancing, which is still called "show". With the increase of the number of people and larger area, small-scale "show" is transformed into relatively larger "public show". If the people watching the show are conscious to attend "show", "public (sth known to everyone; engage in the affairs or service of the peoples, in government) show" will be transformed into "republic (any society in which the members have equal rights and privileges) show". From the perspective of audience, Greek drama also experienced from "watching" to "involvement", from "public" to "republic". As the prototype of the ancient Chinese opera art, Chizhou Nuo opera also regards "republicanism" as their ultimate goal. From form and purpose, the historical relics of both Chinese and Foreign arts share extremely close sense of identity; it is far from the accident and coincidence.

\section{ECONOMIC SOURCES OF NUO OPERA}

Chizhou Nuo opera has always been a conscious behavior of the villagers and are free from any returns in materials. Villagers voluntarily donate money and materials to establish Nuo Opera in their own villages. In the restoration of Nuo Opera, it took larger cost. Utensils, masks, costumes, flag umbrella and gongs, etc. took the majority of the whole cost, in which masks was on the top of the list. In addition, the cost for masks varied from village to village. There are totally 42 masks in Nuo Opera of $\mathrm{Pu}$ Village and they cost over 10,000 RMB that are evenly shouldered by all male villagers in all villages. The cost is calculated and accumulated by the organizer. At present, the economic status quo of Nuo Opera in Chizhou still keeps the original status with slight difference. The main economic sources of Nuo Opera are: equally shared by all male villagers, public subsidy from village government and donation from visitors outside.

TABLE I. BALANCE OF PAYMENT FOR NUO OPERA IN XIE GROUP OF XINTIAN VILLAGE IN 2003

\begin{tabular}{|c|c|c|c|}
\hline $\begin{array}{l}\text { Iten } \\
\text { Balance } \\
\text { of } \\
\text { Payment }\end{array}$ & Items & $\begin{array}{l}\text { Amount } \\
\text { ( RMB) }\end{array}$ & Notes \\
\hline \multirow{4}{*}{ Incomes } & $\begin{array}{l}\text { Donation from } \\
\text { Three household } \\
\text { in the village }\end{array}$ & 90 & $\begin{array}{l}\text { Promise from } \\
\text { the families } \\
\text { who request } \\
\text { Nuo Opera }\end{array}$ \\
\hline & $\begin{array}{l}\text { Donation from } \\
\text { Outside Visitors }\end{array}$ & 400 & $\begin{array}{l}\text { Returns for } \\
\text { Offering } \\
\text { catering and } \\
\text { accommodatin } \\
\text { from villagers } \\
\text { to researchers }\end{array}$ \\
\hline & $\begin{array}{l}\text { Donation from } \\
\text { audience on the } \\
\text { spot }\end{array}$ & 38 & $\begin{array}{l}\text { Poor Mother } \\
\text { Is Alone and } \\
\text { Pathetic in } \\
\text { Opera Liu } \\
\text { Wenlong }\end{array}$ \\
\hline & $\begin{array}{l}\text { Surplus from } \\
\text { last year }\end{array}$ & 86 & \\
\hline \multirow{6}{*}{ Expenses } & One Drum & 122 & \\
\hline & 13 yellow jackets & 186 & \\
\hline & $\begin{array}{l}\text { Yaotai } \\
\text { (refreshment) }\end{array}$ & 24 & $\begin{array}{l}\text { Refreshments } \\
\text { for actors when } \\
\text { Nuo Opera is } \\
\text { over }\end{array}$ \\
\hline & $\begin{array}{l}\text { Candles, false } \\
\text { paper money for } \\
\text { the dead }\end{array}$ & 26 & \\
\hline & $\begin{array}{l}\text { Firecracker and } \\
\text { powder }\end{array}$ & 145 & \\
\hline & others & 45 & Pen and ink \\
\hline \multicolumn{2}{|l|}{ Surplus } & 66 & $\begin{array}{l}\text { For next year } \\
\text { expenses }\end{array}$ \\
\hline
\end{tabular}


The quantity and time of public subsidy is relatively rare. As per Mr. Wang Guiyou, the accountant of Wang Group, Yangchong Village, in the restoration period of Nuo Opera, the subsidy from village government was barely 1,000 RMB and the subsidy was not allocated once again. The main source at that time came from voluntary donation from villagers. In fact, the public subsidy from village government also came from handing in payment. For example, in February, 2002, when Nuo Opera was on the stage in Wang Group of Yangchong village, it is no need to evenly charge from every household because the cost is quite limited. In the same year, the neighboring Xie Group of Xingtian Village spent some money to purchase some costumes for Nuo Opera, including a drum and 13 yellow jackets etc. Mr. Xieshaopu, the organizer had a record in accounting.

Regarding economic incomes of villagers, the main incomes of villagers in Chizhou are: farming, forestry and labor etc. Chizhou is hilly country and has limited arable land, only approximately 0.75 acres of arable land per capita. There is a certain gap among the income of the villagers of different villages. Annual incomes for households in Puzhuang Village range from RMB 2,000 to 5,000; from RMB 2,000 to 3,500 in Gaoxi Village; After having subtracted agricultural tax of RMB 360 to 370 , surcharge in various kinds (approximately $20 \%$ of the agricultural tax), specialty tax (based on sales volume), school-age children tuition, medical costs and other expenses, they have remained little. The economic status of villagers in Chizhou is a typical microcosm of the overall agricultural economy and the overall economic situation of the farmers is that they cannot make both ends meet.

According to the statistics of "Green Paper of the rural economy" and" Economic Blue Book ", the pace of income growth for Chinese farmers had been slow down in 2000 and 2001. Agricultural income, farming income particularly, continued to slow down. In 2000, the average annual income of Chinese farmers was RMB 2,253, up $1.9 \%$ than that of last year, in which, agricultural income was RMB 1,091, decreasing by RMB 48, down 4.3\%. For 1998 and 1999 , the incomes have been reduced RMB 28 and 53 respectively, down $2.3 \%$ and $4.5 \%$. The growth in the overall income of farmers mainly came from the growth in labor income from immigrant workers outside. The average labor income in 2002 was RMB 701, increasing RMB 72, up $11.2 \%$. It is $165 \%$ of net income. The average daily life expenses for rural residents in 2002 was RMB 1,670, up 5\% than that of last year, including food of RMB 820 , accommodating RMB 258, education RMB 187 and medical cost RMB 88 etc. The general situation for Chinese farmers is that they can feed themselves but they do not have any extra money to spend. Therefore, "Green Paper" and "Blue Book" suggest that those non-agricultural industries shall be actively promoted; rural industrial and organizational structure shall be adjusted to speed up the flow and transfer of rural labors, effectively reduce the burden of farmers, increase their incomes and effectively promote their actual living conditions.

\section{TABLE II. AVERAGE ANNUAL INCIMES OF CHINESE FARMERS}

\begin{tabular}{|c|c|c|c|c|c|c|}
\hline \multicolumn{2}{|c|}{ Indicators } & 1985 & 1990 & 1995 & 1999 & 2000 \\
\hline \multirow{5}{*}{$\begin{array}{l}\text { Absolute } \\
\text { Amount } \\
\text { (RMB) }\end{array}$} & $\begin{array}{l}\text { Net } \\
\text { Income }\end{array}$ & 398 & 686 & 1578 & 2210 & 2253 \\
\hline & $\begin{array}{l}\text { Production } \\
\text { Income }\end{array}$ & 368 & 657 & 1480 & 2079 & 2129 \\
\hline & $\begin{array}{l}\text { Agricultural } \\
\text { Income }\end{array}$ & 298 & 511 & 967 & 1180 & 1132 \\
\hline & $\begin{array}{l}\text { Non-Agricultur } \\
\text {-al } \\
\text { Income } \\
\end{array}$ & 69 & 147 & 513 & 899 & 997 \\
\hline & $\begin{array}{l}\text { Non-Production } \\
\text { Income }\end{array}$ & 30 & 29 & 98 & 132 & 124 \\
\hline \multirow{4}{*}{$\begin{array}{l}\text { Ratio } \\
(\%)\end{array}$} & $\begin{array}{l}\text { Production } \\
\text { Income }\end{array}$ & 93 & 96 & 94 & 94 & 95 \\
\hline & $\begin{array}{l}\text { Agricultural } \\
\text { Income }\end{array}$ & 81 & 78 & 67 & 57 & 50 \\
\hline & $\begin{array}{l}\text { Non-Agricultur } \\
\text {-al } \\
\text { Income }\end{array}$ & 18.9 & 22.3 & 32.6 & 43.2 & 44.3 \\
\hline & $\begin{array}{l}\text { Non-Production } \\
\text { Income }\end{array}$ & 7.5 & 4.2 & 6.2 & 6.0 & 5.5 \\
\hline
\end{tabular}

TABLE III. AVERAGE ANNUAL CONSEMPTION STRUCTURE OF CHINESE FAMERS

\begin{tabular}{|c|c|c|c|c|c|c|}
\hline \multicolumn{2}{|c|}{$\begin{array}{l}\text { Consumption } \\
\text { Items }\end{array}$} & 1985 & 1990 & 1995 & 1999 & 2000 \\
\hline \multicolumn{2}{|c|}{$\begin{array}{l}\text { Consumption } \\
\text { Amount (RMB) }\end{array}$} & 317.4 & 584.6 & 1310.4 & 1577.4 & $\begin{array}{c}1670 \\
.1\end{array}$ \\
\hline \multirow{8}{*}{$\begin{array}{l}\text { Ratio } \\
(\%)\end{array}$} & Food & 57.8 & 58.8 & 58.6 & 52.6 & 50.8 \\
\hline & Clothing & 9.7 & 7.8 & 6.2 & 5.8 & 5.7 \\
\hline & $\begin{array}{l}\text { Accomm } \\
\text {-odating }\end{array}$ & 18.2 & 17.3 & 13.9 & 14.8 & 15.4 \\
\hline & $\begin{array}{c}\text { Househo } \\
\text {-ld } \\
\text { articles }\end{array}$ & 5.1 & 5.3 & 5.2 & 5.2 & 4.5 \\
\hline & $\begin{array}{c}\text { Medical } \\
\text { Care }\end{array}$ & 2.4 & 3.3 & 3.2 & 4.4 & 5.3 \\
\hline & $\begin{array}{c}\text { Transpor } \\
\text {-tation }\end{array}$ & 1.7 & 1.4 & 2.6 & 4.4 & 5.3 \\
\hline & $\begin{array}{c}\text { Educatio } \\
\text {-n, } \\
\text { Entertain } \\
\text {-ment }\end{array}$ & 3.9 & 5.4 & 7.8 & 10.7 & 11.2 \\
\hline & Others & 1.2 & 0.7 & 2.5 & 2.1 & 1.8 \\
\hline
\end{tabular}

(Rural Development Institute and etc, Chinese Academy of Social Sciences, 2001:112 118.From 2000 to 2001: China Rural Economic Situation Analysis and Forecast: Beijing, Social Sciences Academic Press; Liu Guoguang and etc, 2001: 138 146, China in 2001: Economic Analysis and Forecast: Beijing, social Sciences Academic Press.)

At present, economic income structure witnesses great changes in China. The ratio of non-farming incomes in various kinds, particularly salary income from labor export enjoyed great growth. The salary of immigrant workers enjoyed the fastest growth. After 1997, rural economy entered into a new stage: for food and other agricultural products, they have transformed from sellers' market into buyers' market that the market was weak, sales were hard and the price was decreased. The agricultural income had been decreased for consecutive years. The reason why 
farmers' incomes could keep low-pace increase was that non-agricultural income grew, in which the labor income of immigrant workers was the main reason. Many households relied on the income of immigrant workers to fill up the gap at home, to pay Santiwutong (three profit deductions and five comprehensive plans in the level of village administration) and taxes in various kinds. It is conducive to ease the contradiction between urban and rural areas, stabilize rural society, which is beneficial to the overall situation. Farmers in Chizhou also joined in the army of immigrant workers in cities, most of them went to Shanghai or Zhejiang Province.

Immigrant workers: It is a huge shift in thinking for Chinese farmers to leave their land and hills that are cultivated for generations into a completely strange world. Based on the fifth population census in 2000, there were 120 million people who left the places where they were born, in which about 80 million people are immigrant workers from rural areas who left their hometown and were employed in the second and third industries in cities and towns. However, temporary leaving their hometowns could not make them abandon their deep affections towards their hometowns. Chinese New Year is the most typical festival to show the aura of happiness and family-gathering. Therefore, as long as Chinese New Year approaches, most of immigrant workers definitely come back to their hometowns. The margined lives in cities, full of loneliness and inhibited emotions for a year have to be released. The immigrant workers who come back to their hometowns are happy to be involved in happy and active Nuo Opera.

Scenes of donation from the audience in Wang and Xie Groups: Although economic incomes of farmers in Chizhou are far from satisfactory. However, regarding the involvement of Nuo Opera, most of them are also active and optimistic. In February 2002 and February 2003, I personally went to watch Nuo Opera in $\mathrm{Pu}$ Village (it is almost the same for the Nuo Opera in Wang Group, Yang Village and Xie Group, Xintian Village). In the section of "Poor old mother was pitiful" of Opera Liu Wenlong, when the audience witnessed the tottering Mother Liu in Opera, the audience actively asked their children to donate some money in the broken basket in the center of Nuo Opera field, the donated money ranged from RMB 1 to 2 . Totally, the amount of donation came to RMB 38 at that evening in Xie Group in 2003. After having deducted the cost for refreshment for actors of RMB 24, there was some surplus.

The donation in Nuo Opera is similar to gratuity money in theaters in formality; they are both the recognition for the performance of actors and content of operas. However, the implications of these two are completely different. In Nuo Opera, the audience on the spot shares the common recognition that Mother Liu in the opera is alone and uncared and that they all show their sympathy towards the weak and respects to the old. Furthermore, the behavior of asking their children to donate the money is actually the education that children shall bear filial piety in their mind, take care and pay respects to the old. However, the gratuity money in the theaters is the approval and encouragement for professional and gorgeous performance of actors. In addition, it plays as incentives to encourage actors to embody more wonderful performance. It is obvious that there are different value orientations of Nuo Opera in rural areas and professional opera performance in theaters. The latter lays emphasis on "art skills" and the former on "meaning".

\section{NUO OPERA ASSOCIATION}

For a long time, regarding folklore activities carrying the characteristics of religion, government departments either lay strict restrictions on them or show indifference towards them. Traditional folklore arts received less attention from governments. Since restoration of Chizhou Nuo Opera, it enjoyed "free" development in some villages in Chizhou. By the end of this century, because of further development and management of tourist resources of Mountain Jiuhua in Chizhou city, Nuo Opera Big Gathering-Mountain Qing Temple Fair in Chizhou near Mountain Jiuhua had the chances to attract attention. With the suggestion and appeal of both domestic and foreign scholars and local experts, local government realized that as the "living fossil "of Chinese opera, Nuo Opera in Chizhou carries particular cultural values, the folk customs embodied inside Nuo Opera in Chizhou and hidden tourist and commercial values of Nuo Opera as the beneficial supplement to Mountain Jiuhua natural resources are perceived.

Mountain Qing Temple Fair takes place in the morning of 13th of the first month in lunar calendar. Nuo Opera gatherings of Liu Group of Nanshan, Yao Group of Dangli, Wang Group of Gaolong, Tang Group of Songshu, Xie Group of Xichong, Sun Group of Hebian, Yao Group of Maotan, Ke Group of Xucun are gathered in the location of town government of Liujie. It is located in Mountain Qing Temple, 600 meters in the west of Liu Group of Nanshan and it is an annual pilgrimage activities. Based on the introduction of the president of Mountain Qing Temple_-Dehui Right Reverend (See the photo on the right: the person in the middle is Dehui Right Reverend), the Buddha worshiped in Mountain Qing Temple is authentic Brahmam Buddha, auntie of Jin Qiaojue, the Brahmam Buddha in Mountain Jiuhua. Therefore, local people commonly believe that the aura of god in Mountain Jiuhua originates from the Buddha of Mountain Qing Temple. Local Buddhists believe that they shall worship the mother of Brahmam Buddha in Mountain Qing Temple and then Brahman Buddha in Mountain Jiuhua because they have to follow the order from the old to the young, otherwise it will be in a mess.

During Annual pilgrimage, each Nuo Opera gathering would invite their Nuo Gods to the empty space in front of Mountain Qing Temple, set up firecrackers, burn the incense and worship accordingly. There is a competition among all Nuo Opera Gatherings to witness which one set up more firecrackers and how loud those firecrackers would be. In addition, they would compete with each other regarding how large their audience is, how large their dragon sedan chair will be. After then, Nuo Dancing is get on the stage and each gathering invites their best dancer to perform Nuo dancing in Temple fair to do their best to win over others 
on gorgeous dancing skills to attract the attention of the leading God of Mountain Qing Temple. In this case, the Nuo God will have more aura of god than that of other villages. In 13th of the first month of lunar Calendar in 2002 (see up left photo, taken by the author, in the year of 2003, on the spot of Mountain Qing Temple Fair), the weather clears up, the worship activities last from 9:00 AM in the morning over noon (12:00 AM), the temple fair pooled over 9,000 people. In the next year, it was raining and extremely somber and cold, there were totally 3,000 people of nine Nuo Opera Gatherings because it happened that International Seminar on Hui Studies and Nuo Opera Studies 2003 was held in Chizhou at the same time, some domestic and foreign representatives also attended Temple Fair at that year. On that day, main government officials also went to the performance site of Liujie Town to conduct research on the project of the development of natural and cultural sightseeing of Mountain Jiuhua and the main topic for discussion was "putting the historical relics of ancient Nuo Opera and ancient memorial temples of Chizhou into tourism development of Mountain Jiuhua”.

About 600 meters away in the east of Mountain Qing Temple, there is the existing ancient ancestral hall of Liu Group of Nanshan Village, one of well-kept ancient ancestral halls in Chizhou area (photo down, taken by Wang Yibin: on the left is restored gate house of ancient Huizhou city; on the right is the gatehouse of left-over ancient ancestral hall of Liu Group of Nanshan Village). It was built in the early days of Qing Dynasty, about 300 years in history. However, the gilded wood carvings on queti(decorated bracket) are still shining and the bases of marble column are also clear and bright. Compared with the adjacent ancestral halls of Ming and Qing Dynasties in Huizhou city, the architectural style of the ancient ancestral halls in Chizhou tends to be more simple and smooth.

There are some similarities between them. Both gatehouses play the role as highlighting momentum, including decorations. They are equipped with wooden structure and cornices are in shape of "Dragon" or "Mountain". Wooden frames are carved with emblazonry of dragon, phoenix and clouds and bases of marble columns are carved with animals of turtle or Bixi (turtle-liked animal) that carries the meaning of auspice, harvest and longevity. They are full of historical and ornamental values. In the first month of lunar calendar, Nuo Opera of Liu Group of Nanshan Village is performed in this ancient ancestral temple. Ancient and vivid dancing performance is staged on classical and elegant ancient ancestral hall. We can be keenly aware of the historical memories when we are involved. It is inevitable to face the transition of time and space.

In such gradually industrialized and commercialized society, for busy modern people, necessary and timely return into human nature is of paramount importance to review history and relax bodies and minds. "Freud believed that with the development of civilization, human nature are more inhibited rather than perfected. Therefore, arts are used to lead off and the desires in subconscious are satisfied in illusion. Arts become a symbol of depression and misery and the best way for life impulse and expression out."3 Ancient Nuo Opera does not simply bring simple historical memory and the deep sense of identity in ancient culture and ancestral heritage due to the involvement in traditional thoughts is the unbreakable blood and emotions for villagers. Only the performance of Nuo Opera Gathering is far from satisfaction to express the worship of villagers towards gods. In the mean time of attending Mountain Qing Temple Fair and being involved in dancing and singing, there is hidden sense of identity in the deep soul of villages. Everyone shares the same origin and have blood relationship and we are close as family.

\section{CONFLICTS AND COMPROMISES}

Hidden conflicts and explicit compromises among various powers in Nuo Opera: the sense of holiness possessed by Nuo Opera in Chizhou originates from the results of the projection of collective consciousness from the piety of villagers and also is the reflection of daily lives of villagers. Poor health, the lack of the access to abundant material and psychological lives makes villagers do not understand the general public and the misunderstanding in reality is reflected in psychological field. In chilly winter nights, they spend four or five hours to watch the opera in still, it is easy for them to create an illusion. When the performance is similar with the scenes happened in their daily lives, the resonance is created. "Drama" is the mirror of daily lives, "role" in the opera reflect true "me". "I" is the "god" and "god" is "I".

Unveiling external appearance, there is mutual and hidden relationship among powers in various kinds. Opera is the mirror of actual lives. Most of the transcripts of many Nuo Opera come from historical stories or folklore fairy tales. Lady Mengjiang and Liu Wenlong are typical folklore stories who expressed the common and well-known belief that "ladies shall be loyal to their husbands from the very beginning to the end"; Shaking Money, also known as Sister Zhang Si Placing Flowers is the wide-spread fairy tale; Officer Bao Plowing Land tells us a historical story and emphasizes that officers shall enforce laws impartially and hold the belief that everyone is equal. Every act of Opera attempts to advocate moral virtues or empowers villagers the sense of satisfaction to grant whatever is requested. Villagers are temporary actors and actresses and are advocates of gods. Villagers do not seek for the artistry of opera, they desire to hide themselves and become lost to realize the effects of contacting gods directly. The purpose is to seek for welfare for whole villagers. "I" in Nuo Opera is not actual "I", "I" is "god" and "I" is the person of foresights and can wipe off dirt, get rid of illness, remove calamities and make villagers enjoy a life of ease and comfort.

In the relationship of "People-God-Actors and Actresses", God is in the center. That is to say, the concept of god is the basic core to maintain the operation of Nuo Opera. For example, "I" play the role as "Lady Mengjiang", actually, "I" am definitely not "Lady Mengjiang". In facts, "I" in the opera has already become the spokesperson of "Lady Mengjiang" and also the spokesperson of kind 
Chinese ladies. Therefore, the female audience on the spot will have relatively high degree of identity in psychology. Nuo Opera, goodness, spectaculars and daily life have become zero distance community. We know that the appealing of villages does not ask for any practical returns. Actually, appealing itself has already acquired some comfort in psychology. Therefore, "regardless that the appealing of followers will be satisfied with the help of gods or not, it is considered as being helpful in belief; the behavior of acting as gods or faeries is actually the symbol of hidden returns, basic requirements for virtues and the realization of promises. This situation indicates four layers of social culture design.

Regarding the first level, we can see that in the belief system of Han culture, they believe that God, ghosts, ancestors and living people exist in the same world. This set of system corresponds to social structure and organization in real world. Regarding the second level, it is obvious in the system that requires strengthened and solid group. Regarding the third level, it is clear that gods can be required and the relationship between gods and human beings are mutually beneficial. Regarding the fourth level, we can find that "life rituals, year of birth in particular (implicitly including the maturity in age, possible regression in social status and the definition of social roles), are highly emphasized."4Since there is mutual interaction in the layer of psychology, we can not clarify many phenomenon in the performance of Nuo Opera. Of course, the performance of Nuo Opera by villagers has definite and clear goal to promote cohesion and increase the influence of this group to realize "republicanism". However, in such influencing public ritual activities, there is the lack of political guidance and the penetration of national consciousness.

Corresponding to the relationship of "Human beings - Gods - Actors and Actresses, regarding the power structure of villages and folklore social consciousness, power allocation of "farmers-local governments - nation" and mutual consciousness interaction can be embodied through Nuo Opera rituals. Nation is assembled community based on certain organizational structure. It represents the mass public to forcefully exercise the administration and organization of political, economic, military and diplomatic powers. Local governments are outlets of nation and represent nation to execute administration power in local places. As an agricultural civilized society, among all social relationship, the most prominent problem is farmer that is the largest group with fastest pace in growth. Furthermore, it is the most unstable, vulnerable and most powerless in face of changes.

With the further deepening of rural modernization, the traditional conservative and feudal sense of farmer economy is facing unprecedented challenges. Open national economic policies, more flexible economic layout, increasing technique ratio in farming, increasing degree of mechanization and great investment in land make that farmers have to bear. However, the value of agricultural products and industrial products are greatly imbalanced, a large amount of industrial products and agricultural machines poured into rural areas without order, which offers chances for brokers with colossal profits. In addition, local governments (especially those local governments with poor economic performance) adopt deceptions for upper governments to show off their management levels, including fake report on public feelings and exaggeration on rural economic incomes. As a consequence, local governments have to levy farmers more taxes to record their meritorious deeds.

These entire additional burdens have already bent the backs of farmers and they are struggling to seek for solutions for the crisis: kind and honest farmers stopped their bloody family fights, clan killing and turn themselves to explore wasteland, but it turns out to be that the outcome could not meet the both ends up. They learned from their mistakes, they followed the tide and tried to be immigrant works. They have to take unfamiliar working styles and adopt long-term or short-term labor services. Only this trial makes their families get out the common dilemma in households of "having food to feed but no extra money to spend". According to incomplete statistics, such as populous provinces like Anhui and Sichuan, salary income of immigrant workers accounted for $20 \%$ of their GDP.

In the above-mentioned Nuo Opera ceremony, the relationship of "Human Being-God-Actors and Actresses" is ideal, in other words, it is harmonious and mutually beneficial. In fact, it is not the case in real life. From the investigation of some place in South Anhui Province, we witnessed the following thing: in order to standardize farming products and achieve scale farming, local government enforced farmers to plant chrysanthemum seedlings that are expected to sell well and ruin seedlings of winter wheat. Therefore, the loss of farmers is subsided with RMB 60 per acre by county government. Worse still, those farmers who are not willing to ruin their well-planted winter wheat seedlings are criticized and enforcedly conducted. Any courts in Chinese history, in order to promote the incomes of farmers, put forward a lot of methods or means to better agricultural business. No matter of Reforms of Shang Yang, Principles of Wang Fu-chih and Reforms of Wang Anshi, they all carry the same goal to persuade rather than enforce farmers, none to say harm the farmers. In general assembly of National People's Congress of 2003, Premier Wen Jiabao put forward Principles of Wang Fu-chih to emphasize that persuading farmers does not mean harming farmers. Those farmers inherited lands from their upper generation are wise enough to generate maximum benefits from their farming, they definitely are aware of which plant suits them best, aren't they?

It is true that farmers almost completely lose the rights to speak in the interaction between urban and rural areas, between local government and themselves. Urban areas need immigrant workers to solve the problem of severe lack of labor-intensive process of urban construction and farmers are usually employed in those fields where need heavy labor services and strong pollution, such as construction, chemicals and toy etc. At present, cities are in strong needs of immigrant workers. Especially during Spring Festival, many services have to be stopped because immigrant workers come back home, such as the stop of construction 
projects and factory assembly line. Furthermore, urban dwellers have no fresh milk served. Even though immigrant workers are important, they are still on the margin of cities. Most of them live or rent houses in suburban districts with poor living conditions and community environment. Their children could not be educated in public schools and their welfare is far from satisfactory, even they are not equipped with basic medical insurance. On one hand, cities are in urgent needs for immigrant workers that are useful and cheap in cost; on the other hand, cities are unwilling to accept immigrant workers, even do not offer basic survival and living rights. Therefore, self-salvation of modern farmers is a thorny road full of obstacles.

\section{Symbol of Nation in Nuo Opera And National RITUALS}

The most striking feature of Nuo Opera is to dramatize daily lives and to deify common people. Holiness is the most fundamental power in maintaining the propagation among the mass public. In real lives, people are ranked and classified. In Nuo Opera, gods are also ranked, in which the most powerful symbol is Jade Emperor in the heaven, followed by local main god and lower local earth gods and minor gods. In folklore belief system all over China, Jade Emperor is the only dominator in the heaven. Therefore, in terms of status, Jade Emperor is located in the highest position.

Nations are the products of class society; the concept of nation only exists in the groups with different levels in class society. Chizhou Nuo Opera is the concentrated expression of ideology of local people. It is carried with obvious and clear class consciousness because it classifies gods into different levels. It is the expression of the concept of nation in Nuo Opera performance; it is the expression of collective consciousness. In Shaking Money of Nuo Opera, in order to realize justice, Officer Bao went to the heaven and invited defied Sister Zhangsi down to earth to grasp the devil in the hell. It described the scene where god, ghost and human being are on the spot at the same time. These plots and stories are pure products of imagination; it is given a strain interpretation. Reasonably speaking, holy world is the ideal home to people where shall be free from hierarchy and everyone shall be equal.

From the perspective of collective consciousness, Chizhou Nuo Opera is holy power organization jointly authorized by villagers. It is also a kind of agreement and joint statement among villagers. Because there shall have constraints in agreement, for villagers themselves, Nuo Opera does not have compulsory constraints and some special features shall be attached. Therefore, holy significance empowered on Nuo Opera is natural results. Turning words into music, actions into Nuo Opera, daytime into night, villagers into Nuo gods, after a series of "dramatization" and "deification", collective consciousness has gained a certain contracted conventional behaviors. Those people who have power to communicate with gods become leaders. Similarly, in real lives, some respectable people become the organizer of Nuo Opera and their sons and decedents become village officers. Those main gods in
Nuo Opera and officers in real lives are the projection of collective consciousness of villagers to empower them certain social values and they will receive common agreement and respect from villagers in returns.

Not only Nuo opera, an ethnic group and a nation also need strengthened collective consciousness and corresponding projection. The strengthened projection is the representative of nation. National emblem, national flag, national anthem, Congress, and laws are all projection of collective consciousness. They used to be common objects, because they are empowered with public consciousness by all citizens. In this sense, they are sublimated as the collective symbol and are authorized with some certain holy powers and unconscious compulsory collective power. Furthermore, the projection of this collective willpower will be constant to maintain the vitality of holy objects.

Therefore, rituals of singing national anthem and flag-raising ceremony are performed every morning and they are often taken place in public places, such as Tianmen Square. The time shall be consistent with the local time of sun rising to fetch the meaning of "brightness and willpower". Thanks to these rituals, the willpower of all Chinese citizens can be standardized. Similarly, at present, for all Chinese people, all the family members shall be gathered in the eve of Spring Festival. Sitting together in front of television is to watch Spring Festival Gala and to embrace the bell of the New Year. At that moment, all Chinese in all over the world celebrate it at the same time to wish our nation and our home prosperous, wealthy and affluent. In essence, national rituals and behaviors carry the same goal with folklore Nuo Opera (This thesis is part of basic research project of state-owned university, Xiamen University. Item No. 2010221094)

\section{REFERENCES}

[1] Alan P. Merriam The Anthropology of Music,Evanston, Ill, Northwestern University Press.

[2] Arthur wolf,Religion and Ritual in Chinese Society,Stanford University Press, 1974.

[3] Bruno Nettlsome, C.J.Frisbie,historical thoughts on the character of Ethnomusicology, Exploration on Ethnomusicology, ed. 1986.

[4] C.G.Jung,The Practice of Psychotherapy,Princeton,Princeton University Press, 1966.

[5] Douglas, Mary 1966 : Purity and Danger : An Analysis of Concepts of Pollution and Taboo. London : Routledge and Kegan Paul. \& Weber, Max 1978 : Economy and Society : An Outline of Interpretive Sociology. Based on 4th German edition. 1956, revised 1964. Edited by Guenther Roth and Claus Wittich. 2 vols. Berkeley: University of California Press.

[6] E. Said,Orientalism,London and New York,Penguin1978.

[7] Fischer, Hans, Sound Producing Instruments in Oceania, Institute of Papua New Guinea Studies, 1986,103-104.

[8] Grimes, Ronale, Beginnings in Ritual Studies (revised edition) , University of South Carolina Press, USA,1995.

[9] Harold F. Abeles, Charles R. Hoffer, Robert H. Klotman Foundations of Music Education,1995.

[10] Lagerwey, John,Taoist Ritual in Chinese Society and History, Macmilan Publishing Company, New York, London,1985. 
[11] Lightstore,J.N \& Bird,F.B Ritual and Ethnic Identity, A Comparative Study of the Social Meaning of Liturgical Ritual in Synagogues, Wilfrid Laurier University Press, 1995.

[12] Schirmer Books,New York, Rentice Hall Internationa,Torontol.

[13] R.Benedict,Patterns of Culture,Boston,Houghton Mifflin, 1934.

[14] Stock, Jonathan P.J. Huju,Traditional Opera in Modern Shanghai,The British Academy by Oxford University Press, 2003,207.

[15] Wassmann, Jürg,The Song to the Flying Fox, Cultural Studies Division The National Research Institute, 1991,255.

[16] Yamada, Yoichi. Songs or Sprits,An Ethnography of Sounds in a Papua New Guinea Society, Institute of Papua New Guinea Studies, 1997,41.

[17] http://www.huixue.org/huixue/show.asp?n=438.

[18] http://iea.cass.cn/jianbao/F000238.doc, 2007-10.

1 S. Freud translated by Lin Chen and etc: "Selection of Freud's Late Writings" Shanghai Translation Publishing House, 1986:77 - 78. English Version of Lebon Writings, 1920:30.

2 Martin - Esslingen, Translated by Luo Wanhua: On Drama, Beijing: Chinese Drama Press, 1984:17.

3 Hu Zhiyi: Fairy Tale and Rituals: On the Prototype of Drama, Shanghai: Xuelin Press, 2001:14.

4 Wang Songshan: "Acting as Gods" and "True Gods": Belief and Rituals in Folklore Operas, Zaichen Shouren 239-240: Empirical Studies on Local Opera. Research project on Cantonese Opera, The Chinese University of Hongkong, 1997. 